\title{
Intralenticular foreign body: leave the quiet ones alone
}

\author{
Raksheeth Nathan Rajagopal, ${ }^{1}$ Muralidhar Ramappa (i) ${ }^{2}$
}

${ }^{1}$ The cornea institute, LV

Prasad Eye Institute, Hyderabad, Telangana, India

${ }^{2}$ The Cornea Institute, L V Prasad Eye Institute, Hyderabad, India; Centre for Rare Eye Diseases and Ocular Genetics, L V Prasad Eye Institute, Hyderabad, India; Jasti V Ramanamma Children's Eye Care Center, LV Prasad Eye Institute, L V Prasad Eye Institute, Hyderabad, Telangana, India

\section{Correspondence to}

Dr Muralidhar Ramappa; muralidhar@|vpei.org

Accepted 26 August 2021

\section{DESCRIPTION}

A 21-year-old man presented to our clinic with pain, redness and watering in his left eye (LE) for 1 day following an alleged history of accidental injury while working using a hammer-chisel. At presentation, corrected distance visual acuity (CDVA) was 20/25. Slit-lamp examination of the LE revealed full-thickness nasal corneal laceration with retained refractile foreign body and iris hole corresponding to the point of entry (figure 1A). Postdilation examination revealed a refractile stone piece embedded within the crystalline lens substance (figure 1B). Fundus examination of the LE was unremarkable, and B-scan did not show posterior segment intraocular foreign body (IOFB). Examination of the right eye was essentially normal. The patient underwent LE wound exploration, corneal foreign body removal and corneal tear repair.
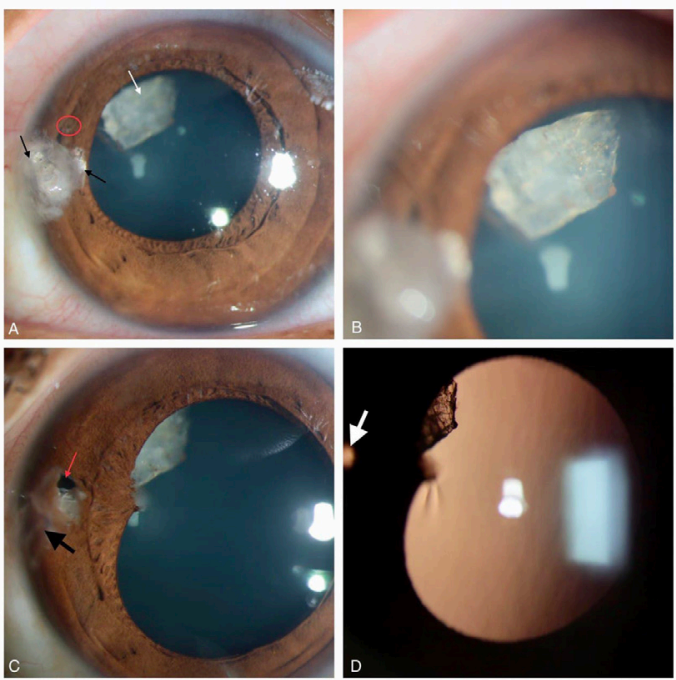

Figure 1 (A) Preoperative image of sealed corneal laceration with foreign body pieces and mucus embedded within the wound (thin black arrows); ILFB seen out of focus (thin white arrow); though difficult to appreciate, a small iris hole is noted corresponding to the entry wound (within red circle). (B) Magnified view showing the refractile nature of the ILFB. (C) One month postoperatively, the healed wound is seen after suture removal (thick black arrow); iris defect is appreciated now (red arrow) with atrophy of iris tissue around it; the inert ILFB is partially obscured by focal posterior synechia. The remaining lens is clear, and there is no intraocular inflammation. (D) Retroillumination view showing the ILFB partially obscured by posterior synechia and transillumination at the site of iris defect (thick white arrow). ILFB, Intralenticular foreign body.
A few angle foreign bodies were noted intraoperatively and were removed. The retrieved foreign bodies were plated on chocolate agar. The intralenticular foreign body (ILFB) was left untouched. A postoperative regimen of topical prednisolone acetate $1 \%$ suspension (Pred Forte, Alcon) in tapering doses and topical moxifloxacin $0.5 \%$ (Vigamox, Alcon) four times a day were initiated. One month postoperatively, CDVA of the LE remained 20/25; sutures were removed; and the ILFB appeared inert with no signs of inflammation, infection or glaucoma. The culture results at 1 week were negative for microbial growth. The visual axis of the LE was clear, with no signs of cataractous lens changes. Focal posterior synechia was noted at the lens-capsule entry site (figure 1C,D). Steroid drops were tapered down over the next 2 weeks, and antibiotic drops were prescribed for a week following suture removal, along with protective glasses.

Four months postoperatively, the LE clinically remained status quo (figure $2 \mathrm{~A}, \mathrm{~B}$ ), and Schiempflug imaging (figure 2C) delineated the depth and nature of the foreign body.

LFBs are rare, comprising 7\%-10\% of all IOFBs. ${ }^{1}$ Most of these foreign bodies are metallic and require lens extraction due to ocular inflammation, glaucoma or metallosis. ${ }^{2}$ Glass and most plastic IOFBs tend to be inert, eliciting minimal or no inflammatory reaction. ${ }^{3}$ Moreover, these
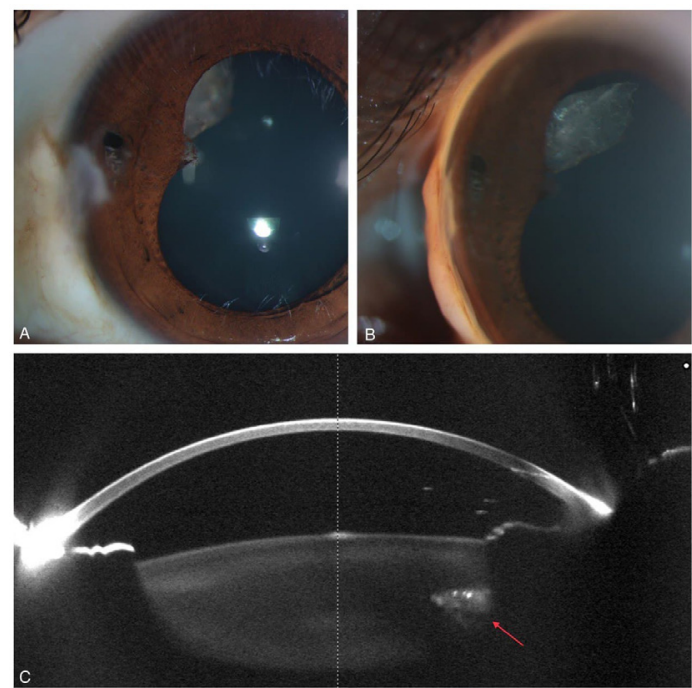

Figure $2(A, B)$ Four months postoperatively, the crystalline lens remains completely clear, with no signs of focal or diffuse cataractous changes. (C) Schiempflug imaging delineates the visible part of the refractile foreign body, seen at mid-lens depth (red arrow). 
materials are associated with lower endophthalmitis rates compared with vegetative matter and metallic objects. ${ }^{4}$ The foreign body in our case appears to resemble glass-like material, possibly being composed of similar constituent chemical compounds. The extraction of inert ILFBs outside the visual axis can be deferred if they are not accompanied by the complications described previously. ${ }^{5-7}$ While retained IOFBs are associated with increased rates of endophthalmitis (up to three times more than for penetrating trauma alone), this was mainly due to posterior lens capsular breach and delayed primary repair, ${ }^{8}$ both of which were fortunately not seen in our patient. The diagnosis of ILFB is often straightforward by slit-lamp examination, but care must be taken to rule out posterior segment IOFB by B-scan or CT scan. These patients will require regular follow-up, and lens extraction should be planned at the first sign of complications due to the foreign body.

Acknowledgements The authors thank Raja shekar and Washeem Mohammed of Hyderabad Eye Research Foundation for capturing the clinical images.

Contributors Data collection, manuscript writing and review of literature: RNR; manuscript review and approval: MR; operating surgeon: RNR.

Funding The authors have not declared a specific grant for this research from any funding agency in the public, commercial or not-for-profit sectors.

Competing interests None declared.

Patient consent for publication Obtained.

Provenance and peer review Not commissioned; externally peer reviewed.

\section{ORCID iD}

Muralidhar Ramappa http://orcid.org/0000-0003-3667-5483

\section{Learning points}

Inert intralenticular foreign bodies can be observed as long as they do not cause any intraocular complications.

- Lens-sparing primary repair preserves accommodation and helps avoid major intraocular surgery (Extra Capsular Catarcat Extraction (ECCE), Intra capsular Catarcat Extraction (ICCE) and phacoemulsification) and its accompanying complications, especially in this young patient group.

- The presence of posterior segment intraocular foreign body/ posterior capsular breach in such cases must always be ruled out by thorough examination and appropriate imaging.

\section{REFERENCES}

1 Percival SP. A decade of intraocular foreign bodies. Br J Ophthalmol 1972;56:454-61.

2 Lin Y-C, Kuo C-L, Chen Y-M. Intralenticular foreign body: a case report and literature review. Taiwan J Ophthalmol 2019;9:53.

3 Archer DB, Davies MS, Kanski JJ. Non-metallic foreign bodies in the anterior chamber Br J Ophthalmol 1969;53:453-6.

4 Duan F, Yuan Z, Liao J, et al. Incidence and risk factors of intraocular foreign bodyrelated endophthalmitis in southern China. J Ophthalmol 2018;2018:1-5.

5 Arora R, Sanga L, Kumar M, et al. Intralenticular foreign bodies: report of eight cases and review of management. Indian J Ophthalmol 2000;48:119-22.

6 Foss AJ, Forbes JE, Morgan J. An intralenticular foreign body and a clear lens. Br J Ophthalmol 1993;77:828.

7 Dhawahir-Scala FE, Kamal A. Intralenticular foreign body: a D-day reminder. Clin Exp Ophthalmol 2005;33:659-60.

8 Essex RW, Yi Q, Charles PGP, et al. Post-traumatic endophthalmitis. Ophthalmology 2004;111:2015-22.

Copyright 2021 BMJ Publishing Group. All rights reserved. For permission to reuse any of this content visit

https://www.bmj.com/company/products-services/rights-and-licensing/permissions/

BMJ Case Report Fellows may re-use this article for personal use and teaching without any further permission.

Become a Fellow of BMJ Case Reports today and you can:

- Submit as many cases as you like

- Enjoy fast sympathetic peer review and rapid publication of accepted articles

- Access all the published articles

- Re-use any of the published material for personal use and teaching without further permission

Customer Service

If you have any further queries about your subscription, please contact our customer services team on +44 (0) 2071111105 or via email at support@bmj.com.

Visit casereports.bmj.com for more articles like this and to become a Fellow 